\title{
A Multi-Criteria Analysis Based Technique to Integrate Socio Economic and Geo-Physical Aspects in Risk Sensitive Land Use Plan: A Case Study on Mirsharai Upazila, Chattogram District, Bangladesh
}

\author{
${ }^{[1]}$ ANM Safiqul Alam, \\ GEOMARK LIMITED, \\ Dhaka, Bangaldesh
}

\begin{abstract}
Bangladesh is a developing and densely populated country. The process of urbanization is increasing day by day in this country. But planned development is challenging here. Bangladesh is the largest delta in the world. Due to geographical location, Bangladesh is naturally prone to disasters. Not only that Bangladesh is also under the thread of global worming and climate change related issues. Although Bangladesh is not contributing much to global greenhouse gas increase, Bangladesh is one of the largest victims of the adverse impacts of global worming and climate change. To reduce the impact and damage it is necessary to formulate risk reduction land use plan incorporating socioeconomic and geo-physical aspects. Mirsharai is a coastal Upazila situated in Chattogram District of Bangladesh. The area is highly prone to disaster and affected by climate change related problems. So, the area is ideal for this kind of study. In this paper, socioeconomic characteristics such as affordability, investment potentiality, demand and need has been analyzed. Result shows that people's affordability is not good in most of the places of Mirsharai Upazila but in some isolated areas like small urban area or growth centres, people's affordability and other socioeconomic conditions are good. Geo-physical aspects such as Infrastructure, ground water recharge, water logging tendency, Road accessibility, Ground elevation, Agricultural crop pattern and Land use were used to calculate development suitability and development conflict using Multi-criteria Analysis technique. Based on development suitability and conflict 4 category were identified as highly suitable, suitable, moderately suitable and less suitable area for development. Similarly, highly conflicted, conflicted, moderately conflicted and less conflicted areas for development were identified. Finally, by comparing development conflict and suitability maps, a relative development suitability map was produced marking highly suitable, suitable, moderately suitable, less suitable, partially unsuitable and completely unsuitable areas for development. These types of socioeconomic and geo-physical condition analysis can help making clear understanding on the study area for making risk sensitive land use plan.
\end{abstract}

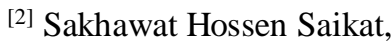 \\ Bangladesh University of Engineering and Technology, \\ Dhaka, Bangaldesh
}

Keywords:- Disaster and Climate change resilience, Risk sensitive Land use Plan, Multi-criteria Analysis.

\section{INTRODUCTION}

Urban centers in developing countries like Bangladesh have witnessed tremendous changes in terms of population growth and urban expansion. without proper urban management planning practices, rapid increase in population creates huge challenges to government agencies in providing adequate shelter to the millions of homeless and poor in urban areas. Urban growth due to in-migration triggers the increase in population density. The migration of people from rural to urban areas for better job opportunities, better standard of living and higher level of education is expected to continue in coming future which may lead to shortage of facilities and increasing demand of land for residential purposes.

It is becoming increasingly challenging to acquire new site for urban development or improvement particularly in a growing real estate market and with stringent environmental standards or regulations. The site suitability analysis result highlights of the most-suitable areas for consideration of placement of a certain facility, while filtering out unusable or less desirable sites. Certain aspects may have more importance than others in determining the best location for each facility. Suitable site selection for specific uses must be based upon a set of criteria depending on local norms. A rating system may be applied to the varied aspects of suitableness to assess the general suitableness for a selected urban use (Kumar and Shaikh, 2012).

Geographic information systems (GIS) serve the multicriteria analysis function of suitability assessment well, providing the attribute values for every location and each the arithmetic and logical operators for combining attributes (Jiang and Eastman 2000). moreover, the multicriteria analysis is also used to develop and measure various plans that will facilitate compromise among interested parties (Malczewski, 1996). Land suitability means the ability of a specific type of land to support a particular use. Generally, the process of land suitability classification includes the evaluation and grouping of specific land areas in terms of their suitability for a defined use (Prakash, 2003). Land suitability analysis is thus concerned with fitness evaluation 
of a given land parcel for a defined use (Steiner, et al. 2000). In other words, it is the process of determining whether the land is suitable for some specific uses. It also determines the suitability level of 5that particular land parcel. To determine the most appropriate direction for future development, the suitability for various land uses should be carefully examined for directing growth to the most appropriate manner. Determining appropriate suitability factors is the most fundamental part of suitability analysis. Land Suitability analysis was developed as a method for planners to relate spatially independent factors within the environment and, thus to provide a more unique view of their interactions. Suitability analysis techniques mainly integrates three factors of an area which are location, development activities, and biophysical/ environmental processes (Miller et al., 1998). So, the goal of land suitability analysis is to identify the most appropriate spatial pattern for future land uses based on specific requirements, preferences, or predictors of some activity (Collins et al., 2001).

Physical planning comprises of spatial arrangement relating to physical resources to achieve functional efficiency, public safety and aesthetic quality. Physical/structure planning is primarily concerned with good management and development of land. Strategic Planning provides the mechanism for making comprehensive decision about the use of land and resources. It is an approach that intertwines all segments related to social, economic, physical and environmental dimensions. Many countries, like third world countries have rapidly urbanized and developed in an unplanned manner. Many continue to do so in an unprecedented rate. This has generated the conversion of forest lands, agricultural lands, wetlands, and aquifer recharge areas to industrial and urban uses. This trend has enormous impacts on productive agricultural lands and ecological resources and ecosystems. Industrial and urban development has likewise led to the segregation of land uses, e.g. separation of residential houses, shopping centers, and employment centers. Such land use development patterns have impacts on energy and resource consumption, which have turned out to be unsustainable for humanity, i.e. emergence of global warming and climate change. This paper intends to examine different socio economic and geo-physical aspects to determine development suitability of land in the light of disaster and climate change resilience. This might be considered as a framework for making risk sensitive physical/ land use plan.

\section{STUDY AREA}

Mirsharai is located at $22.7722^{\circ} \mathrm{N} 91.5750^{\circ} \mathrm{E}$. It has 55771 households and total area $482.88 \mathrm{~km}^{2}$. Mirsharai is an upazila of Chattogram District in the division of Chattogram, Bangladesh. It consists 2 Thana and 2 Pauroshava. Two thanas are Jorargonj and Mirsharai; two Pauroshavas are Baraiyarhat and Mirsharai. (BBS, 1991)

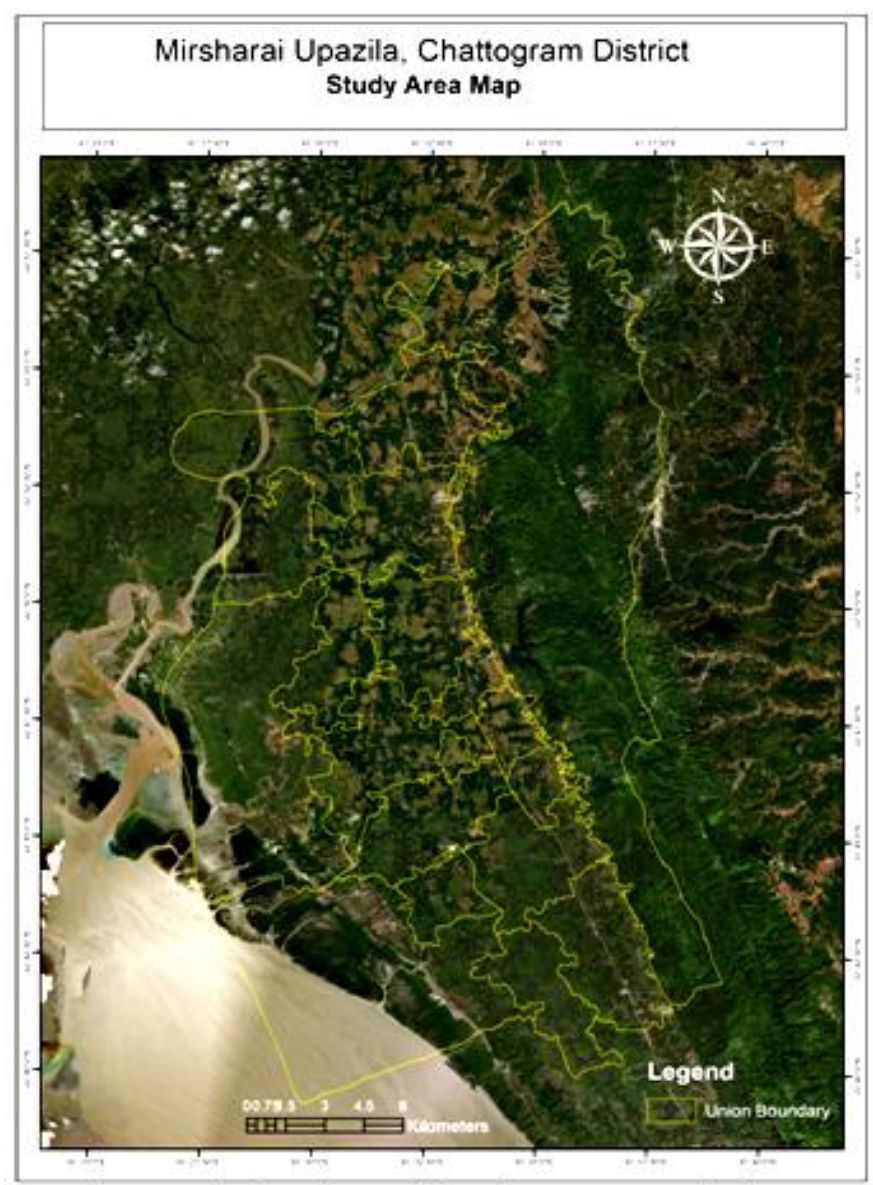

Fig. 1:- Mirsharai Upazila, Chattogram District

\section{SOCIO ECONOMIC ASPECTS ANALYSIS}

\section{A. Local savings and potentiality}

Investment is the key driver for any type of development. Investments generally comes from Entrepreneurs, Government investment, foreign aid etc. but local investment like, micro investment from higher middleor middle-income group can also contribute to the overall development. People do savings for the future so that they can invest the money to achieve economic solvency and security in days to come. So, today's savings can be a potential source of investment in future. During the survey, no direct response from the people were taken whether they are willing to invest but response has been taken about their income, expenditure in different sectors, saving status etc. Using that knowledge, their savings pattern has been analyzed from spatial perspective. A map has been produced with 3 (Low, moderate, high) types of potentially based on savings intensity. This map is not based on actual willingness to invest but based on local people's savings pattern from which a clear understanding about the economic strength and potentiality can be made. In Mirsharai upazila, highly potential areas are concentrated within the proximity of urban areas. 


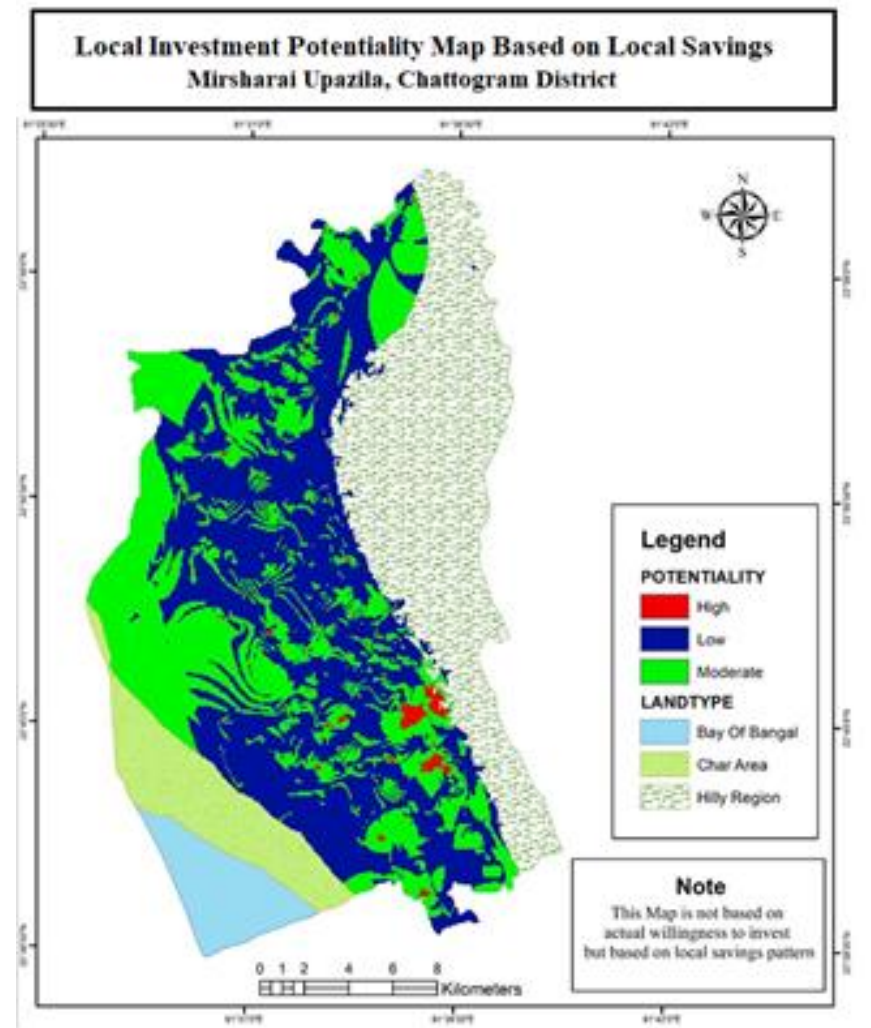

Fig. 2:- Local Investment potentiality map

\section{B. 5.2 Affordability assessment}

A GIS based Spatial Model has been developed to calculate people's affordability on spatial perspective. Several raster maps were prepared for Monthly Income, Expenditure on Food, Cloth, Utility, Education, Children, and Health care, Transport, Total Monthly Expenditure and Monthly Savings. All these raster maps were used in the model as variable maps. Relative weightage was assigned for each variable raster according to their relative influence and impact on affordability.

Variables weight distribution were as follows,

\begin{tabular}{|c|c|c|c|c|}
\hline Variable & $\begin{array}{l}\text { Influe } \\
\text { nce }\end{array}$ & Value Range & $\begin{array}{l}\text { Assigned } \\
\text { Value }\end{array}$ & $\begin{array}{l}\text { Scale } \\
\text { value }\end{array}$ \\
\hline \multirow{5}{*}{$\begin{array}{l}\text { Expenditure } \\
\text { on Child }\end{array}$} & \multirow{5}{*}{8} & $<100$ & 1 & 1 \\
\hline & & 100-199 & 2 & 4 \\
\hline & & $200-299$ & 3 & 6 \\
\hline & & $300+$ & 4 & 9 \\
\hline & & NO DATA & $\begin{array}{l}\text { NO } \\
\text { DATA }\end{array}$ & $\begin{array}{l}\text { NO } \\
\text { DATA }\end{array}$ \\
\hline \multirow{9}{*}{$\begin{array}{l}\text { Expenditure } \\
\text { on Cloth }\end{array}$} & \multirow{9}{*}{8} & $<900$ & 1 & 1 \\
\hline & & $1,000-1,900$ & 2 & 3 \\
\hline & & $2,000-2,900$ & 3 & 4 \\
\hline & & $3,000-3,900$ & 4 & 5 \\
\hline & & $4,000-4,900$ & 5 & 6 \\
\hline & & $5,000-5,900$ & 6 & 7 \\
\hline & & $6,000-6,900$ & 7 & 9 \\
\hline & & $7,000+$ & 8 & 9 \\
\hline & & NO DATA & $\begin{array}{l}\text { NO } \\
\text { DATA }\end{array}$ & $\begin{array}{l}\text { NO } \\
\text { DATA }\end{array}$ \\
\hline
\end{tabular}

ISSN No:-2456-2165

\begin{tabular}{|c|c|c|c|c|}
\hline \multirow{9}{*}{$\begin{array}{l}\text { Expenditure } \\
\text { on } \\
\text { Education }\end{array}$} & \multirow{9}{*}{8} & $<1000$ & 1 & 1 \\
\hline & & $1,000-1,9000$ & 2 & 3 \\
\hline & & $2,000-2,900$ & 3 & 4 \\
\hline & & $3,000-3,900$ & 4 & 5 \\
\hline & & $4,000-4,900$ & 5 & 6 \\
\hline & & $5,000-5,900$ & 6 & 7 \\
\hline & & $6,000-6,900$ & 7 & 8 \\
\hline & & $7,000+$ & 8 & 9 \\
\hline & & NO DATA & $\begin{array}{l}\text { NO } \\
\text { DATA }\end{array}$ & $\begin{array}{l}\text { NO } \\
\text { DATA }\end{array}$ \\
\hline \multirow{8}{*}{$\begin{array}{l}\text { Expenditure } \\
\text { on Food }\end{array}$} & \multirow{8}{*}{8} & $<5,000$ & 1 & 1 \\
\hline & & $5,000-9,000$ & 2 & 3 \\
\hline & & $\begin{array}{l}10,000-14,00 \\
0\end{array}$ & 3 & 4 \\
\hline & & $\begin{array}{l}15,000-19,00 \\
0\end{array}$ & 4 & 5 \\
\hline & & $\begin{array}{l}20,000-24,00 \\
0\end{array}$ & 5 & 6 \\
\hline & & $\begin{array}{l}25,000-29,00 \\
0\end{array}$ & 6 & 8 \\
\hline & & $\begin{array}{l}30,000-34,00 \\
0\end{array}$ & 7 & 9 \\
\hline & & NO DATA & $\begin{array}{l}\text { NO } \\
\text { DATA }\end{array}$ & $\begin{array}{l}\text { NO } \\
\text { DATA }\end{array}$ \\
\hline \multirow{8}{*}{$\begin{array}{l}\text { Expenditure } \\
\text { on Health }\end{array}$} & \multirow{8}{*}{8} & $<900$ & 1 & 1 \\
\hline & & $1,000-1,900$ & 2 & 3 \\
\hline & & $2,000-2,900$ & 3 & 5 \\
\hline & & $3,000-3,900$ & 4 & 6 \\
\hline & & $4,000-4,900$ & 5 & 7 \\
\hline & & $5,000-5,900$ & 6 & 8 \\
\hline & & $6000+$ & 7 & 9 \\
\hline & & NO DATA & $\begin{array}{l}\text { NO } \\
\text { DATA }\end{array}$ & $\begin{array}{l}\text { NO } \\
\text { DATA }\end{array}$ \\
\hline \multirow{12}{*}{$\begin{array}{l}\text { House hold } \\
\text { Expenditure }\end{array}$} & \multirow{12}{*}{14} & $<5,000$ & 1 & 1 \\
\hline & & $5,000-9,000$ & 2 & 2 \\
\hline & & $\begin{array}{l}10,000-14,00 \\
0\end{array}$ & 3 & 3 \\
\hline & & $\begin{array}{l}15,000-19,00 \\
0\end{array}$ & 4 & 4 \\
\hline & & $\begin{array}{l}20,000-24,00 \\
0\end{array}$ & 5 & 5 \\
\hline & & $\begin{array}{l}25,000-29,00 \\
0\end{array}$ & 6 & 6 \\
\hline & & $\begin{array}{l}30,000-34,00 \\
0\end{array}$ & 7 & 7 \\
\hline & & $\begin{array}{l}35,000-39,00 \\
0\end{array}$ & 8 & 8 \\
\hline & & $\begin{array}{l}40,000-44,00 \\
0\end{array}$ & 9 & 9 \\
\hline & & $\begin{array}{l}45,000-49,00 \\
0\end{array}$ & 10 & 9 \\
\hline & & $50,000+$ & 11 & 9 \\
\hline & & NO DATA & $\begin{array}{l}\text { NO } \\
\text { DATA }\end{array}$ & $\begin{array}{l}\text { NO } \\
\text { DATA }\end{array}$ \\
\hline
\end{tabular}




\begin{tabular}{|c|c|c|c|c|}
\hline \multirow{12}{*}{$\begin{array}{l}\text { Household } \\
\text { Income }\end{array}$} & \multirow{12}{*}{16} & $<5,000$ & 1 & 1 \\
\hline & & $5,000-9,000$ & 2 & 2 \\
\hline & & $\begin{array}{l}10,000-14,00 \\
0\end{array}$ & 3 & 3 \\
\hline & & $\begin{array}{l}15,000-19,00 \\
0\end{array}$ & 4 & 4 \\
\hline & & $\begin{array}{l}20,000-24,00 \\
0\end{array}$ & 5 & 5 \\
\hline & & $\begin{array}{l}25,000-29,00 \\
0\end{array}$ & 6 & 6 \\
\hline & & $\begin{array}{l}30,000-34,00 \\
0\end{array}$ & 7 & 7 \\
\hline & & $\begin{array}{l}35,000-39,00 \\
0\end{array}$ & 8 & 8 \\
\hline & & $\begin{array}{l}40,000-44,00 \\
0\end{array}$ & 9 & 9 \\
\hline & & $\begin{array}{l}45,000-49,00 \\
0\end{array}$ & 10 & 9 \\
\hline & & $50,000+$ & 11 & 9 \\
\hline & & NO DATA & $\begin{array}{l}\text { NO } \\
\text { DATA }\end{array}$ & $\begin{array}{l}\text { NO } \\
\text { DATA }\end{array}$ \\
\hline \multirow{10}{*}{$\begin{array}{l}\text { Expenditure } \\
\text { on Transport }\end{array}$} & \multirow{10}{*}{8} & $<500$ & 1 & 1 \\
\hline & & $500-900$ & 2 & 2 \\
\hline & & $1,000-1,400$ & 3 & 3 \\
\hline & & $1,500-1,900$ & 4 & 4 \\
\hline & & $2,000-2,400$ & 5 & 5 \\
\hline & & $2,500-2,900$ & 6 & 6 \\
\hline & & $3,000-3,400$ & 7 & 7 \\
\hline & & $4,000-4,900$ & 8 & 8 \\
\hline & & $5,000+$ & 9 & 9 \\
\hline & & NO DATA & $\begin{array}{l}\text { NO } \\
\text { DATA }\end{array}$ & $\begin{array}{l}\text { NO } \\
\text { DATA }\end{array}$ \\
\hline \multirow{12}{*}{$\begin{array}{l}\text { Expenditure } \\
\text { on Utility }\end{array}$} & \multirow{12}{*}{8} & $<500$ & 1 & 1 \\
\hline & & $500-900$ & 2 & 2 \\
\hline & & $1,000-1,400$ & 3 & 3 \\
\hline & & $1,500-1,900$ & 4 & 4 \\
\hline & & $2,000-2,400$ & 5 & 5 \\
\hline & & $2,500-2,900$ & 6 & 6 \\
\hline & & $3,000-3,400$ & 7 & 7 \\
\hline & & $3,500-3,900$ & 8 & 8 \\
\hline & & $4,000-4,400$ & 9 & 9 \\
\hline & & $5,000-5,400$ & 10 & 9 \\
\hline & & $6,000+$ & 11 & 9 \\
\hline & & NO DATA & $\begin{array}{l}\text { NO } \\
\text { DATA }\end{array}$ & $\begin{array}{l}\text { NO } \\
\text { DATA } \\
\end{array}$ \\
\hline \multirow{4}{*}{ Savings } & \multirow{4}{*}{14} & Low & 1 & 1 \\
\hline & & Moderate & 2 & 5 \\
\hline & & High & 3 & 9 \\
\hline & & NO DATA & $\begin{array}{l}\text { NO } \\
\text { DATA }\end{array}$ & $\begin{array}{l}\text { NO } \\
\text { DATA }\end{array}$ \\
\hline
\end{tabular}

Table 1
House hold income, Expenditure and Savings were given highest influence because they are the most influential factors. But to estimate affordability, it is required to incorporate other expenditures like, Expenditure on Food, Cloth, Utility, Education, Children, and Health care, Transport etc. so; in this model those aspects were incorporated as well but with less influence than household total income, expenditure and savings. Altogether, their weighted average will represent overall affordability. The model output map represents the relative affordability for different land parcels of the project area. The higher the affordability score, the better the affordability of the people living on that particular region. In Mirsharai Upazila, most of the areas are indicated as less affordability oriented.

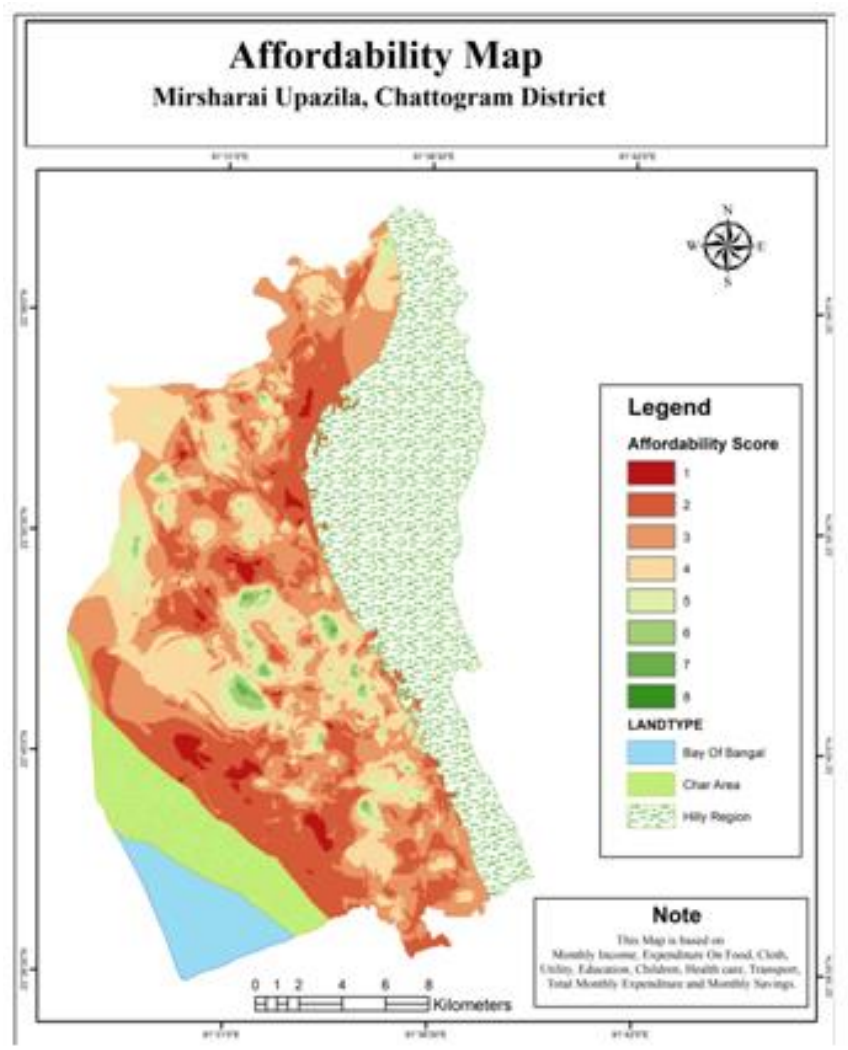

Fig. 3:- Affordability Map

\section{Need and Demand Oriented Area}

In general sense, need usually refers to the fundamental necessities essential for survival or at least to maintain a minimum standard of living. But if affordability goes high, people can dream for more and that creates demand. In countries like Bangladesh, it is very unlikely to find a lot of people having the fancy opportunity of demand, rather than struggling just to fulfil the marginal daily survival amenities they need. To map the Need and Demand oriented areas in the project area another model was formed. As extreme high-income group with huge level of affordability is pretty rare and even certain level of rich people having the ability to afford demand are not too available, so, 6, 7, 8 scored areas can be categorized as demand-oriented areas and 1 to 5 as Need oriented areas. In Mirsharai Upazila, only a small portion of the areas were found as demand-oriented area. 


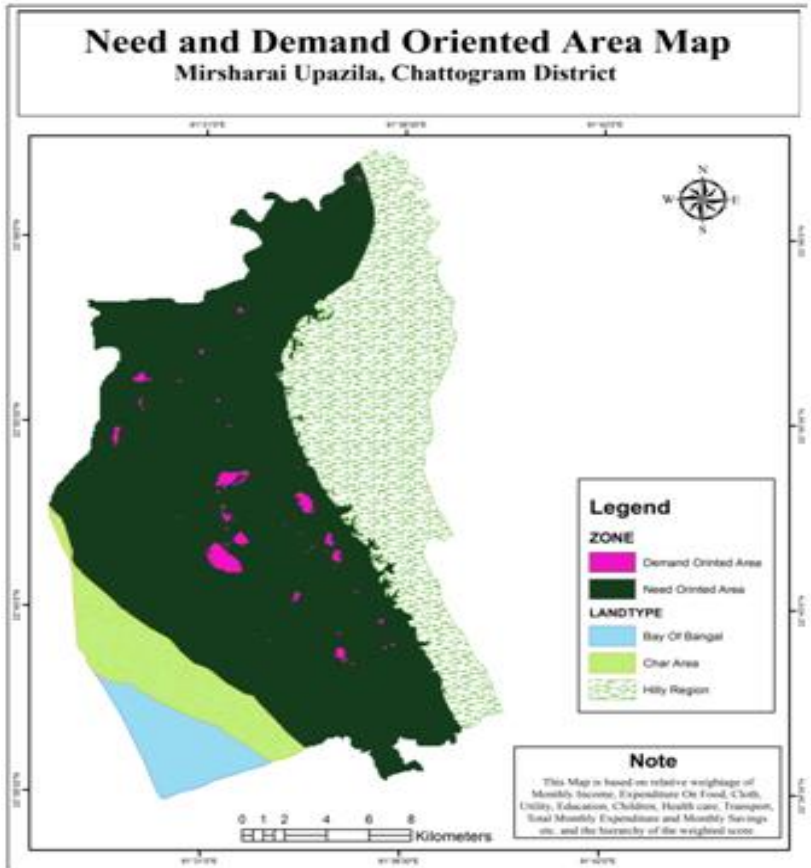

Fig. 4:- Need and Demand Oriented area Map

\section{Urban and Rural distribution of Need and Demand Oriented Areas}

From the spatial distribution pattern of different demand-oriented areas, we can see that most of the demand-oriented areas are either located inside or proximity to the urban areas. There are significant numbers of demand-oriented areas are located near growth centre, and rural markets. So, it can be interpreted that, people living proximity to urban areas, growth centres, and rural markets tends to have better affordability that those who don't. So, areas close to growth centres and rural markets are potential for new development activities.

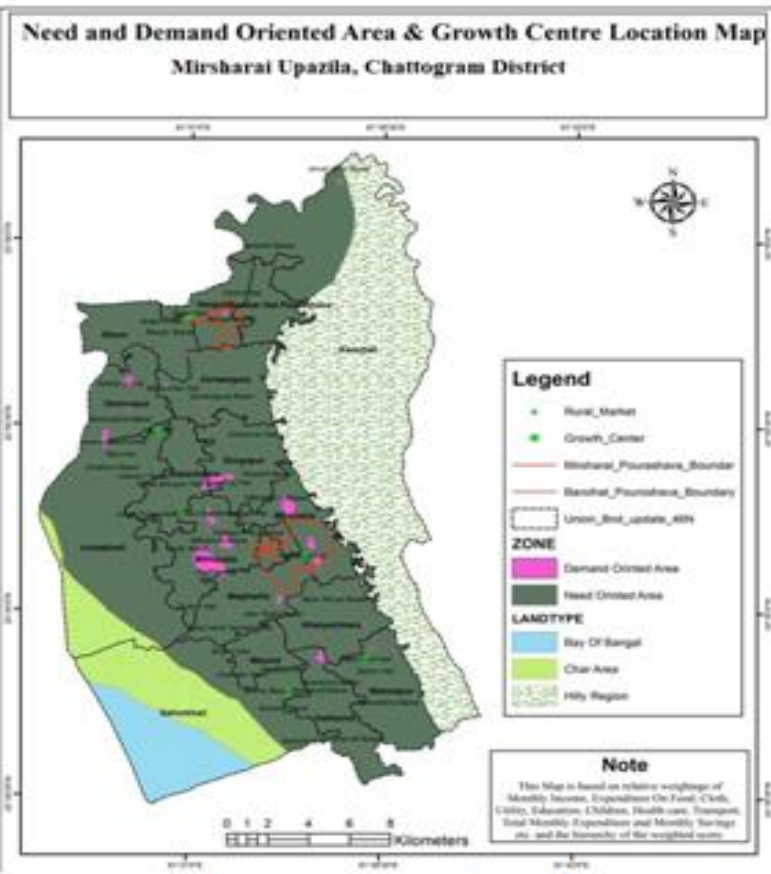

Fig. 5:- Need \& Demand oriented area and growth centre location

\section{URBAN SUITABILITY CALCULATION}

Urban Land suitability is the fitness of a given type of land for a defined use. The land may be considered in its present condition or after improvements. The process of land suitability classification is the appraisal and grouping of specific areas of land in terms of their suitability for defined uses. In short, urban suitability defines how suitable any specific land is for any defined development activity. Urban suitability for Mirsharai upazila has been calculated from GIS based Multi-criteria Analysis (MCA), based on the relative suitability score from Infrastructure Suitability, ground water recharge, water logging tendency, Road accessibility, Ground elevation, Agricultural crop pattern and Land use. The total process has been done in 3 steps. MCA Model used for development suitability Analysis is shown in fig. 06.

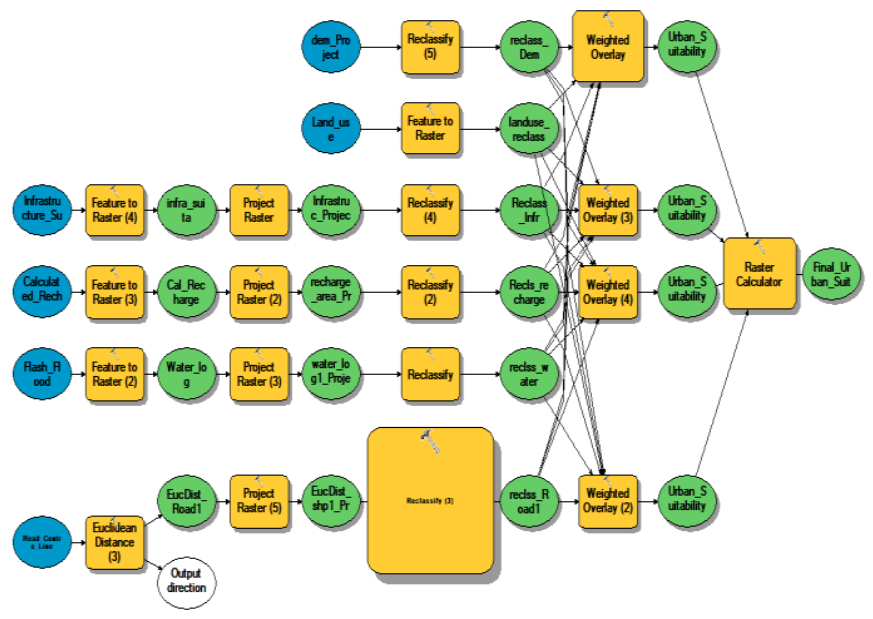

Fig.06 MCA Model for Development Suitability Analysis

\section{E. Data Normalization}

MCA process involves an overlay operation which requires all data in the same value range. In this study, all the data type and their ranges were different that's why; a normalization process was required to reclassify them in a same numeric range and type. In this study, values from different variables such as, Infrastructure Suitability, ground water recharge, water logging tendency, Road accessibility, Ground elevation were reclassified based on their relative influence and suitability in a scale of 1 to 5 , that means, the best suitable range has been given the value 5 and least suitable range has been assigned as 1 , Score 2 to 4 also distributed accordingly. For, Infrastructure Suitability, the highest value was considered as 5 and the lowest was considered as 1 .

\begin{tabular}{|c|c|}
\hline \multicolumn{2}{|c|}{ Reclassification of Infrastructure Suitability } \\
\hline Old Values & New Values \\
\hline Moderate & 3 \\
\hline Hill & 1 \\
\hline Good & 4 \\
\hline Very Good & 5 \\
\hline Poor & 2 \\
\hline River & 1 \\
\hline NO DATA & NO DATA \\
\hline
\end{tabular}


ISSN No:-2456-2165

But for ground water recharge, it is not a good idea to waste lands with good recharge score, so, in this case, the lowest amount of recharge value was considered good and valued as 5 and other levels accordingly.

\begin{tabular}{|c|c|}
\hline \multicolumn{2}{|c|}{ Reclassification of Ground water Recharge } \\
\hline Old Values & New Values \\
\hline $69.541263-194.628609$ & 4 \\
\hline Hill & 1 \\
\hline $0.000000-69.541262$ & 5 \\
\hline $194.628610-318.503119$ & 3 \\
\hline $434.744239-500.049993$ & 1 \\
\hline $318.503120-434.744238$ & 2 \\
\hline NO DATA & NO DATA \\
\hline
\end{tabular}
Table 3

Water logging tendency has negative impact on development activities, so, places with lower water logging tendency were assigned the highest value 5 and other levels accordingly.

\begin{tabular}{|c|c|}
\hline \multicolumn{2}{|c|}{ Reclassification of Water Logging } \\
\hline Old Values & New Values \\
\hline 2nd Degree Sensitive to Water Logging & 4 \\
\hline 4th Degree Sensitive to Water Logging & 2 \\
\hline 3rd Degree Sensitive to Water Logging & 3 \\
\hline 5th Degree Sensitive to Water Logging & 1 \\
\hline 1st Degree Sensitive to Water Logging & 5 \\
\hline NO DATA & NO DATA \\
\hline
\end{tabular}

Table 4

Road accessibility is also vital in development activities, distance from road was also considered. Here, the closest pixels were given the highest values (5) and the score decreased up to 1 with the increase of distance.

\begin{tabular}{|c|c|}
\hline \multicolumn{2}{|c|}{ Reclassification of Distance from Road } \\
\hline Old Values & New Values \\
\hline $0-1083.485596$ & 5 \\
\hline $1083.485596-2598.486084$ & 4 \\
\hline $2598.486084-4269.84082$ & 3 \\
\hline $4269.84082-6332.699707$ & 2 \\
\hline $6332.699707-10493.901367$ & 1 \\
\hline NO DATA & NO DATA \\
\hline Table 5
\end{tabular}

For ground elevation, 2 to 4 Meter was considered the most suitable range for development purposes. So, 2 to 4 Meter was given the highest value. Other values were assigned as the following table...

\begin{tabular}{|c|c|}
\hline \multicolumn{2}{|c|}{ Reclassification of DEM } \\
\hline Old Values & New Values \\
\hline$-4.264498-0$ & 1 \\
\hline $0-2$ & 3 \\
\hline $2-4$ & 5 \\
\hline $4-6$ & 4 \\
\hline $6-8$ & 2 \\
\hline $8-240.867264$ & 1 \\
\hline NO DATA & NO DATA \\
\hline
\end{tabular}

Land use data was not normalized because each land use type act as individual variable and individual weighted score were assigned for each land use type during the overlay operation.

\section{F. Overlay Operation}

In overlay operation, each category from each variable was assigned score ranging from (1-9) based on their suitability. As, in normalization process, a common range of comparative score (1-5) based on suitability was given for DEM, Infrastructure, Ground water recharge, Distance from Road, and water logging, the scores were rescaled between 1 to 9. But for land use, individual category of uses was assigned scores between 1 to 9 based on their suitability for development. For any development work, it is always better to occupy unused and vacant land as much as possible. So, Vacant land was given the highest score 9. Unfortunately, both in urban and rural area, vacant lands are hard to find. So, the second alternative is agricultural lands. But while occupying agricultural land, it is important to keep in mind that it is a threat to the national Agro production and food security. Keeping that in mind, we preferred to occupy Single Crop Agri Land and Double Crop Agri Land if necessary, preserving the Triple Crop Agri Land. So, we preferred the score 8 for Single Crop Agri Land, 6 for Double Crop Agri Land and 4 for Triple Crop Agri Land. For commercial lands, we preferred the score 5. Though commercial lands are already occupied for development purposes, those can be regenerated as well. There were also some similar activity and uses like, Residential, Health Facility, Service Activity, road etc. which can be regenerated as well and scored 5. For water body, we preferred the score 3 because they are low land therefore less suitable for development activity and preservation of natural water sources is a raising concern. Recreation, Community Services, Education \& Research and Miscellaneous uses important for development works. So, preserving the existing ones is the best option. So, a lower score 3 is good enough for those uses. There were some important uses which we had decided to keep untouched such as Forest, Administrative use, Economic Zone, and mixed uses.

Then, for each variable, their influence factor was assigned within $100 \%$. Based on their influence, 4 type of output were generated. At first, equal influence for each variable, secondly, Infrastructure suitability was given highest influence, thirdly, water logging was given highest influence, and lastly, land use was given the highest 
ISSN No:-2456-2165

influence. So, 4 different output maps were generated based on 4 different scenarios. The following tables are showing the exact influence and scores for each variable.

\begin{tabular}{|c|c|c|c|}
\hline \multicolumn{4}{|c|}{ Equal Influence for each variable } \\
\hline Variable & Influence & Field & Score \\
\hline \multirow[t]{5}{*}{ DEM } & \multirow[t]{5}{*}{16} & 1 & 1 \\
\hline & & 2 & 3 \\
\hline & & 3 & 5 \\
\hline & & 4 & 7 \\
\hline & & 5 & 9 \\
\hline \multirow[t]{5}{*}{ Infrastructure } & \multirow[t]{5}{*}{16} & 1 & 1 \\
\hline & & 2 & 3 \\
\hline & & 3 & 5 \\
\hline & & 4 & 7 \\
\hline & & 5 & 9 \\
\hline \multirow{5}{*}{$\begin{array}{l}\text { Ground water } \\
\text { recharge }\end{array}$} & \multirow[t]{5}{*}{16} & 1 & 1 \\
\hline & & 2 & 3 \\
\hline & & 3 & 5 \\
\hline & & 4 & 7 \\
\hline & & 5 & 9 \\
\hline \multirow{5}{*}{$\begin{array}{l}\text { Distance from } \\
\text { Road }\end{array}$} & \multirow[t]{5}{*}{16} & 1 & 1 \\
\hline & & 2 & 3 \\
\hline & & 3 & 5 \\
\hline & & 4 & 7 \\
\hline & & 5 & 9 \\
\hline \multirow{5}{*}{$\begin{array}{l}\text { Water } \\
\text { Logging }\end{array}$} & \multirow[t]{5}{*}{16} & 1 & 1 \\
\hline & & 2 & 3 \\
\hline & & 3 & 5 \\
\hline & & 4 & 7 \\
\hline & & 5 & 9 \\
\hline \multirow[t]{20}{*}{ Land Use } & \multirow[t]{20}{*}{16} & $\begin{array}{l}\text { Single Crop } \\
\text { Agri Land }\end{array}$ & 8 \\
\hline & & $\begin{array}{l}\text { Double Crop } \\
\text { Agri Land }\end{array}$ & 6 \\
\hline & & $\begin{array}{l}\text { Triple Crop } \\
\text { Agri Land }\end{array}$ & 4 \\
\hline & & Commercial & 5 \\
\hline & & Waterbody & 3 \\
\hline & & Vacant & 9 \\
\hline & & Forest & 1 \\
\hline & & Recreation & 3 \\
\hline & & Residential & 5 \\
\hline & & Industrial & 7 \\
\hline & & $\begin{array}{l}\text { Community } \\
\text { Services }\end{array}$ & 3 \\
\hline & & $\begin{array}{ll}\text { Education } \quad \& \\
\text { Research }\end{array}$ & 3 \\
\hline & & Administrative & 1 \\
\hline & & Health Facility & 5 \\
\hline & & Economic Zone & 1 \\
\hline & & Service Activity & 5 \\
\hline & & Miscellaneous & 3 \\
\hline & & Mixed Use & 1 \\
\hline & & Road & 5 \\
\hline & & NO DATA & $\begin{array}{l}\text { NO } \\
\text { DATA }\end{array}$ \\
\hline
\end{tabular}

\begin{tabular}{|c|c|c|c|}
\hline Variable & Influence & Field & Score \\
\hline \multirow[t]{5}{*}{ DEM } & \multirow[t]{5}{*}{12} & 1 & 1 \\
\hline & & 2 & 3 \\
\hline & & 3 & 5 \\
\hline & & 4 & 7 \\
\hline & & 5 & 9 \\
\hline \multirow[t]{5}{*}{ Infrastructure } & \multirow[t]{5}{*}{30} & 1 & 1 \\
\hline & & 2 & 3 \\
\hline & & 3 & 5 \\
\hline & & 4 & 7 \\
\hline & & 5 & 9 \\
\hline \multirow{5}{*}{$\begin{array}{l}\text { Ground water } \\
\text { recharge }\end{array}$} & \multirow[t]{5}{*}{12} & 1 & 1 \\
\hline & & 2 & 3 \\
\hline & & 3 & 5 \\
\hline & & 4 & 7 \\
\hline & & 5 & 9 \\
\hline \multirow{5}{*}{$\begin{array}{l}\text { Distance from } \\
\text { Road }\end{array}$} & \multirow[t]{5}{*}{12} & 1 & 1 \\
\hline & & 2 & 3 \\
\hline & & 3 & 5 \\
\hline & & 4 & 7 \\
\hline & & 5 & 9 \\
\hline \multirow[t]{5}{*}{ Water Logging } & \multirow[t]{5}{*}{17} & 1 & 1 \\
\hline & & 2 & 3 \\
\hline & & 3 & 5 \\
\hline & & 4 & 7 \\
\hline & & 5 & 9 \\
\hline \multirow[t]{20}{*}{ Land Use } & \multirow[t]{20}{*}{17} & $\begin{array}{ll}\text { Single Crop } \\
\text { Agri Land }\end{array}$ & 8 \\
\hline & & $\begin{array}{l}\text { Double Crop } \\
\text { Agri Land }\end{array}$ & 6 \\
\hline & & $\begin{array}{l}\text { Triple Crop Agri } \\
\text { Land }\end{array}$ & 4 \\
\hline & & Commercial & 5 \\
\hline & & Waterbody & 3 \\
\hline & & Vacant & 9 \\
\hline & & Forest & 1 \\
\hline & & Recreation & 3 \\
\hline & & Residential & 5 \\
\hline & & Industrial & 7 \\
\hline & & $\begin{array}{l}\text { Community } \\
\text { Services }\end{array}$ & 3 \\
\hline & & $\begin{array}{l}\text { Education } \quad \& \\
\text { Research }\end{array}$ & 3 \\
\hline & & Administrative & 1 \\
\hline & & Health Facility & 5 \\
\hline & & Economic Zone & 1 \\
\hline & & Service Activity & 5 \\
\hline & & Miscellaneous & 3 \\
\hline & & Mixed Use & 1 \\
\hline & & Road & 5 \\
\hline & & NO DATA & $\begin{array}{l}\text { NO } \\
\text { DATA }\end{array}$ \\
\hline
\end{tabular}

Table 8

Table 7 
ISSN No:-2456-2165

\begin{tabular}{|c|c|c|c|}
\hline \multicolumn{4}{|c|}{ Water logging has the highest influence } \\
\hline Variable & Influence & Field & Score \\
\hline \multirow[t]{5}{*}{ DEM } & \multirow[t]{5}{*}{12} & 1 & 1 \\
\hline & & 2 & 3 \\
\hline & & 3 & 5 \\
\hline & & 4 & 7 \\
\hline & & 5 & 9 \\
\hline \multirow[t]{5}{*}{ Infrastructure } & \multirow[t]{5}{*}{17} & 1 & 1 \\
\hline & & 2 & 3 \\
\hline & & 3 & 5 \\
\hline & & 4 & 7 \\
\hline & & 5 & 9 \\
\hline \multirow{5}{*}{$\begin{array}{l}\text { Ground water } \\
\text { recharge }\end{array}$} & \multirow[t]{5}{*}{12} & 1 & 1 \\
\hline & & 2 & 3 \\
\hline & & 3 & 5 \\
\hline & & 4 & 7 \\
\hline & & 5 & 9 \\
\hline \multirow{5}{*}{$\begin{array}{l}\text { Distance from } \\
\text { Road }\end{array}$} & \multirow[t]{5}{*}{12} & 1 & 1 \\
\hline & & 2 & 3 \\
\hline & & 3 & 5 \\
\hline & & 4 & 7 \\
\hline & & 5 & 9 \\
\hline \multirow[t]{5}{*}{ Water Logging } & \multirow[t]{5}{*}{30} & 1 & 1 \\
\hline & & 2 & 3 \\
\hline & & 3 & 5 \\
\hline & & 4 & 7 \\
\hline & & 5 & 9 \\
\hline \multirow[t]{20}{*}{ Land Use } & \multirow[t]{20}{*}{17} & $\begin{array}{l}\text { Single Crop } \\
\text { Agri Land }\end{array}$ & 8 \\
\hline & & $\begin{array}{l}\text { Double Crop } \\
\text { Agri Land }\end{array}$ & 6 \\
\hline & & $\begin{array}{l}\text { Triple Crop } \\
\text { Agri Land }\end{array}$ & 4 \\
\hline & & Commercial & 5 \\
\hline & & Waterbody & 3 \\
\hline & & Vacant & 9 \\
\hline & & Forest & 1 \\
\hline & & Recreation & 3 \\
\hline & & Residential & 5 \\
\hline & & Industrial & 7 \\
\hline & & $\begin{array}{l}\text { Community } \\
\text { Services }\end{array}$ & 3 \\
\hline & & $\begin{array}{l}\text { Education \& } \\
\text { Research }\end{array}$ & 3 \\
\hline & & Administrative & 1 \\
\hline & & Health Facility & 5 \\
\hline & & Economic Zone & 1 \\
\hline & & Service Activity & 5 \\
\hline & & Miscellaneous & 3 \\
\hline & & Mixed Use & 1 \\
\hline & & Road & 5 \\
\hline & & NO DATA & $\begin{array}{l}\text { NO } \\
\text { DATA }\end{array}$ \\
\hline
\end{tabular}

Table 9

\begin{tabular}{|c|c|c|c|}
\hline \multicolumn{4}{|c|}{ Land use has the highest influence } \\
\hline Variable & Influence & Field & Score \\
\hline \multirow[t]{5}{*}{ DEM } & \multirow[t]{5}{*}{12} & 1 & 1 \\
\hline & & 2 & 3 \\
\hline & & 3 & 5 \\
\hline & & 4 & 7 \\
\hline & & 5 & 9 \\
\hline \multirow[t]{5}{*}{ Infrastructure } & \multirow[t]{5}{*}{17} & 1 & 1 \\
\hline & & 2 & 3 \\
\hline & & 3 & 5 \\
\hline & & 4 & 7 \\
\hline & & 5 & 9 \\
\hline \multirow{5}{*}{$\begin{array}{l}\text { Ground water } \\
\text { recharge }\end{array}$} & \multirow[t]{5}{*}{12} & 1 & 1 \\
\hline & & 2 & 3 \\
\hline & & 3 & 5 \\
\hline & & 4 & 7 \\
\hline & & 5 & 9 \\
\hline \multirow{5}{*}{$\begin{array}{l}\text { Distance from } \\
\text { Road }\end{array}$} & \multirow[t]{5}{*}{12} & 1 & 1 \\
\hline & & 2 & 3 \\
\hline & & 3 & 5 \\
\hline & & 4 & 7 \\
\hline & & 5 & 9 \\
\hline \multirow[t]{5}{*}{ Water Logging } & \multirow[t]{5}{*}{17} & 1 & 1 \\
\hline & & 2 & 3 \\
\hline & & 3 & 5 \\
\hline & & 4 & 7 \\
\hline & & 5 & 9 \\
\hline \multirow[t]{20}{*}{ Land Use } & \multirow[t]{20}{*}{30} & $\begin{array}{l}\text { Single Crop } \\
\text { Agri Land }\end{array}$ & 8 \\
\hline & & $\begin{array}{l}\text { Double Crop } \\
\text { Agri Land }\end{array}$ & 6 \\
\hline & & $\begin{array}{l}\text { Triple Crop } \\
\text { Agri Land }\end{array}$ & 4 \\
\hline & & Commercial & 5 \\
\hline & & Waterbody & 3 \\
\hline & & Vacant & 9 \\
\hline & & Forest & 1 \\
\hline & & Recreation & 3 \\
\hline & & Residential & 5 \\
\hline & & Industrial & 7 \\
\hline & & $\begin{array}{l}\text { Community } \\
\text { Services }\end{array}$ & 3 \\
\hline & & $\begin{array}{l}\text { Education \& } \\
\text { Research }\end{array}$ & 3 \\
\hline & & Administrative & 1 \\
\hline & & Health Facility & 5 \\
\hline & & Economic Zone & 1 \\
\hline & & Service Activity & 5 \\
\hline & & Miscellaneous & 3 \\
\hline & & Mixed Use & 1 \\
\hline & & Road & 5 \\
\hline & & NO DATA & $\begin{array}{l}\text { NO } \\
\text { DATA }\end{array}$ \\
\hline
\end{tabular}

Table 10 


\section{G. Development Suitability Map}

Finally, to achieve the most reliable result, an average of these four outputs from four different conditions were calculated and considered as the final suitability map for Mirsharai Upazila development Plan (MUDP) project area.

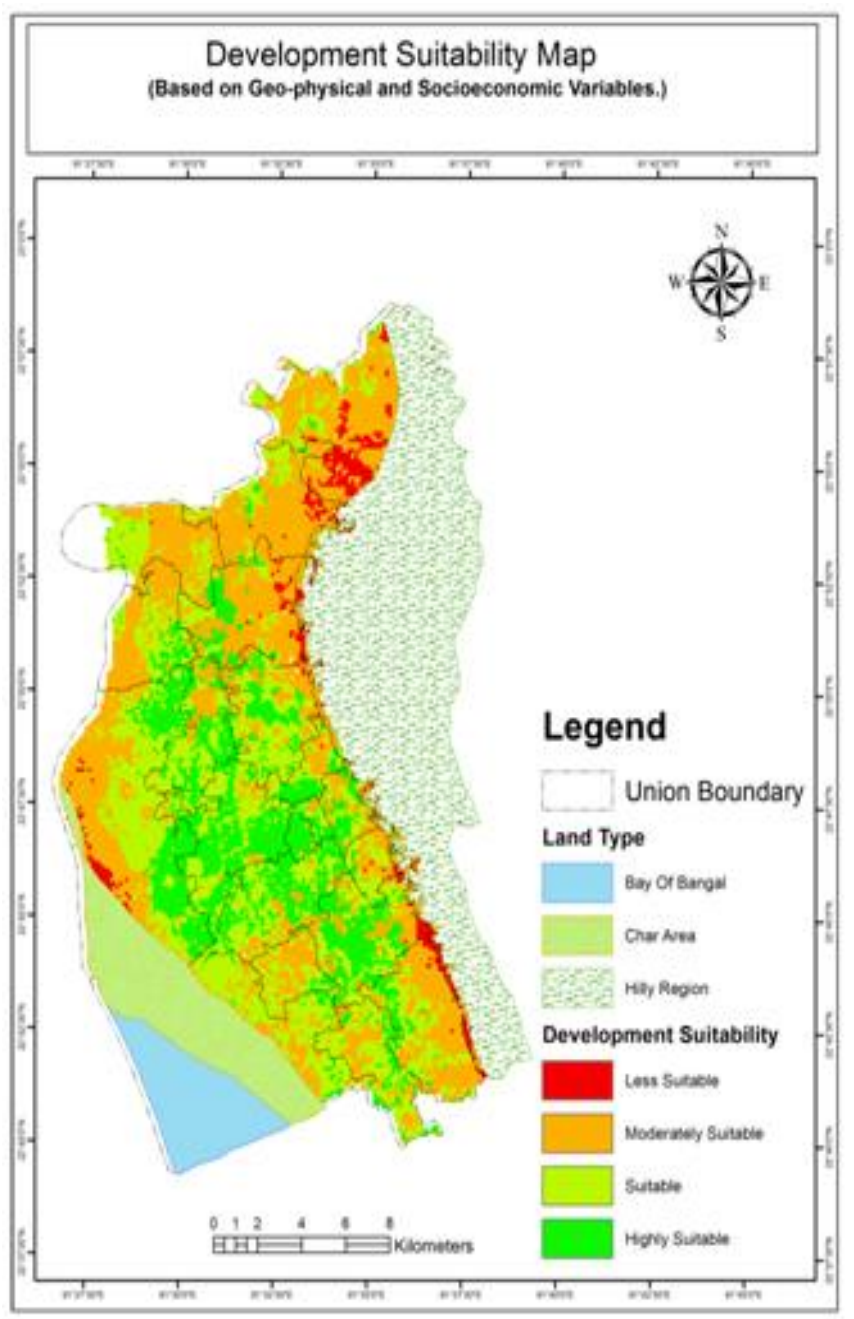

Fig 7:- Development Suitability Map

\section{DEVELOPMENT CONFLICTS CALCULATION}

Development conflicts define how difficult it is to go for any type of development activities in any specific land. In Short, it is the opposite of development suitability. Development Conflicts for Mirsharai Upazila Development Plan Area has been calculated from GIS based Multi-criteria Analysis (MCA), based on the relative Conflict score from Infrastructure Suitability, ground water recharge, water logging tendency, Road accessibility, Ground elevation, Agricultural crop pattern and Land use. Though, Development suitability and conflicts are quite opposite in nature but the process of calculating them are quite similar. The total process has been done in 3 steps, just like development suitability. Fig.08 is showing MCA Model for development conflict Analysis.

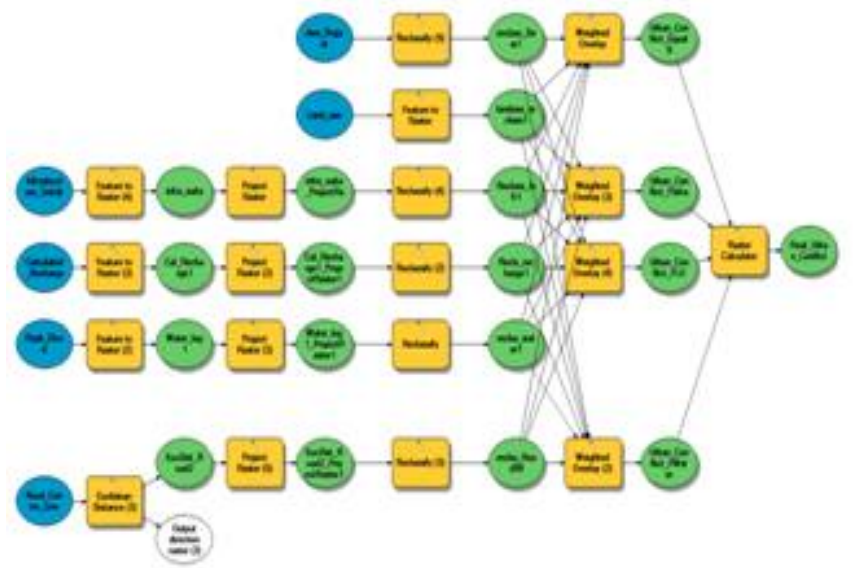

Fig. 8:- MCA Model for development conflict Analysis

\section{H. Data Normalization}

In this study, values from different variables such as, Infrastructure Suitability, ground water recharge, water logging tendency, Road accessibility, Ground elevation were reclassified based on their relative influence and conflicts in a scale of 1 to 5 , that means, the highest conflict range has been given the value 5 and least conflict range has been assigned as 1, Score 2 to 4 also distributed accordingly. For, Infrastructure Conflict, the highest value was considered as 5 and the lowest was considered as 1 .

\begin{tabular}{|c|c|}
\hline \multicolumn{2}{|c|}{ Reclassification of Infrastructure Conflicts } \\
\hline Old Values & New Values \\
\hline Moderate & 3 \\
\hline Hill & 5 \\
\hline Good & 2 \\
\hline Very Good & 1 \\
\hline Poor & 4 \\
\hline River & 5 \\
\hline NO DATA & NO DATA \\
\hline
\end{tabular}

Table 11

But for ground water recharge, it is not a good idea to waste lands with good recharge score, so, in this case, the highest amount of recharge value was considered highly conflicted and valued as 5 and other levels accordingly.

\begin{tabular}{|c|c|}
\hline \multicolumn{2}{|c|}{ Reclassification of Ground water Recharge } \\
\hline Old Values & New Values \\
\hline $69.541263-194.628609$ & 2 \\
\hline Hill & 5 \\
\hline $0.000000-69.541262$ & 1 \\
\hline $194.628610-318.503119$ & 3 \\
\hline $434.744239-500.049993$ & 5 \\
\hline $318.503120-434.744238$ & 4 \\
\hline NO DATA & NO DATA \\
\hline \multicolumn{2}{|c}{ Table 12} \\
\end{tabular}


Water logging tendency has negative impact on development activities, so, places with higher water logging tendency were assigned the highest value 5 and other levels accordingly.

\begin{tabular}{|l|l|}
\hline \multicolumn{2}{|l|}{ Reclassification of Water Logging } \\
\hline Old Values & New Values \\
\hline 2nd Degree Sensitive to Water Logging & 2 \\
\hline 4th Degree Sensitive to Water Logging & 4 \\
\hline 3rd Degree Sensitive to Water Logging & 3 \\
\hline 5th Degree Sensitive to Water Logging & 5 \\
\hline 1st Degree Sensitive to Water Logging & 1 \\
\hline NO DATA & NO DATA \\
\hline
\end{tabular}

\section{Table 13}

Road accessibility is also vital in development activities, so, the far from the access of road the harder it will be to take any development initiative there. Here, the closest pixels were given the lowest values (1) and the score increased up to 5 with the increase of distance.

\begin{tabular}{|l|l|}
\hline Reclassification of Distance from Road \\
\hline Old Values & New Values \\
\hline $0-1083.485596$ & 1 \\
\hline $1083.485596-2598.486084$ & 2 \\
\hline $2598.486084-4269.84082$ & 3 \\
\hline $4269.84082-6332.699707$ & 4 \\
\hline $6332.699707-10493.901367$ & 5 \\
\hline NO DATA & NO DATA \\
\hline
\end{tabular}

Table 14

For ground elevation, 2 to 4 Meter was considered the most suitable range for development purposes, so, this range has the lowest conflicts. So, 2 to 4 Meter was given the Lowest Conflict value. Other values were assigned as the following table.

\begin{tabular}{|c|c|}
\hline \multicolumn{2}{|c|}{ Reclassification of DEM } \\
\hline Old Values & New Values \\
\hline$-4.264498-0$ & 5 \\
\hline $0-2$ & 3 \\
\hline $2-4$ & 1 \\
\hline $4-6$ & 2 \\
\hline $6-8$ & 4 \\
\hline $8-240.867264$ & 5 \\
\hline NO DATA & NO DATA \\
\hline
\end{tabular}

Table 15

Land use data was not normalized because each land use type act as individual variable and individual weighted score were assigned for each land use type during the overlay operation.

\section{Overlay Operation}

In overlay operation, each category from each variable was assigned score ranging from (1-9) based on their conflict values. As, in normalization process, a common range of comparative score (1-5) based on Conflict was given for DEM, Infrastructure, Ground water recharge, Distance from Road, and water logging, the scores were rescaled between 1 to 9. But for land use, individual category of uses was assigned scores between 1 to 9 based on their conflict possibility for development. For any development work, it is always better to occupy unused and vacant land as much as possible. So, Vacant land was considered as the least conflict and given the lowest score 1. Unfortunately, both in urban and rural area, vacant lands are hard to find. So, the second alternative is agricultural lands. But while occupying agricultural land, it is important to keep in mind that it is a threat to the national Agro production and food security. So, agricultural lands have conflict with development works. Keeping that in mind, we preferred we preferred the score 1 for Single Crop Agri Land, 3 for Double Crop Agri Land and 9 for Triple Crop Agri Land. For commercial lands, Residential, Health Facility, Service Activity, road etc. which can be regenerated at some extent, were scored 5. For water body, we preferred the score 7 because they are low land therefore less suitable for development activity and preservation of natural water sources is a raising concern. Recreation, Community Services, Education \& Research and Miscellaneous uses are important for development works. So, preserving the existing ones is the best option. So, a higher score 7 is good enough for those uses. There were some important uses which we had decided to keep untouched therefor given the highest score 9 such as Forest, Administrative use, Economic Zone, and mixed uses.

Then, for each variable, their influence factor was assigned within $100 \%$. Based on their influence, 4 type of output were generated. At first, equal influence for each variable, secondly, Infrastructure Conflict was given highest influence, thirdly, water logging was given highest influence, and lastly, land use was given the highest influence. So, 4 different output maps were generated based on 4 different scenarios. The following tables are showing the exact influence and scores for each variable.

\begin{tabular}{|c|c|c|c|}
\hline \multicolumn{4}{|c|}{ Equal Influence for each variable } \\
\hline Variable & Influence & Field & Score \\
\hline \multirow[t]{5}{*}{ DEM } & \multirow[t]{5}{*}{16} & 1 & 1 \\
\hline & & 2 & 3 \\
\hline & & 3 & 5 \\
\hline & & 4 & 7 \\
\hline & & 5 & 9 \\
\hline \multirow[t]{5}{*}{ Infrastructure } & \multirow[t]{5}{*}{16} & 1 & 1 \\
\hline & & 2 & 3 \\
\hline & & 3 & 5 \\
\hline & & 4 & 7 \\
\hline & & 5 & 9 \\
\hline \multirow{5}{*}{$\begin{array}{l}\text { Ground water } \\
\text { recharge }\end{array}$} & \multirow[t]{5}{*}{16} & 1 & 1 \\
\hline & & 2 & 3 \\
\hline & & 3 & 5 \\
\hline & & 4 & 7 \\
\hline & & 5 & 9 \\
\hline
\end{tabular}


ISSN No:-2456-2165

\begin{tabular}{|c|c|c|c|}
\hline \multirow{5}{*}{$\begin{array}{l}\text { Distance from } \\
\text { Road }\end{array}$} & \multirow[t]{5}{*}{16} & 1 & 1 \\
\hline & & 2 & 3 \\
\hline & & 3 & 5 \\
\hline & & 4 & 7 \\
\hline & & 5 & 9 \\
\hline \multirow{5}{*}{$\begin{array}{l}\text { Water } \\
\text { Logging }\end{array}$} & \multirow[t]{5}{*}{16} & 1 & 1 \\
\hline & & 2 & 3 \\
\hline & & 3 & 5 \\
\hline & & 4 & 7 \\
\hline & & 5 & 9 \\
\hline \multirow[t]{20}{*}{ Land Use } & \multirow[t]{20}{*}{16} & $\begin{array}{l}\text { Single Crop } \\
\text { Agri Land }\end{array}$ & 1 \\
\hline & & $\begin{array}{l}\text { Double Crop } \\
\text { Agri Land }\end{array}$ & 3 \\
\hline & & $\begin{array}{l}\text { Triple Crop } \\
\text { Agri Land }\end{array}$ & 9 \\
\hline & & Commercial & 7 \\
\hline & & Waterbody & 5 \\
\hline & & Vacant & 5 \\
\hline & & Forest & 9 \\
\hline & & Recreation & 7 \\
\hline & & Residential & 7 \\
\hline & & Industrial & 6 \\
\hline & & $\begin{array}{l}\text { Community } \\
\text { Services }\end{array}$ & 7 \\
\hline & & $\begin{array}{l}\text { Education \& } \\
\text { Research }\end{array}$ & 7 \\
\hline & & Administrative & 9 \\
\hline & & Health Facility & 6 \\
\hline & & Economic Zone & 9 \\
\hline & & Service Activity & 5 \\
\hline & & Miscellaneous & 7 \\
\hline & & Mixed Use & 9 \\
\hline & & Road & 7 \\
\hline & & NO DATA & $\begin{array}{l}\text { NO } \\
\text { DATA }\end{array}$ \\
\hline
\end{tabular}

\begin{tabular}{|c|c|c|c|}
\hline & & 5 & 9 \\
\hline \multirow{5}{*}{$\begin{array}{l}\text { Water } \\
\text { Logging }\end{array}$} & \multirow[t]{5}{*}{17} & 1 & 1 \\
\hline & & 2 & 3 \\
\hline & & 3 & 5 \\
\hline & & 4 & 7 \\
\hline & & 5 & 9 \\
\hline \multirow[t]{20}{*}{ Land Use } & \multirow[t]{20}{*}{17} & $\begin{array}{l}\text { Single Crop } \\
\text { Agri Land }\end{array}$ & 1 \\
\hline & & $\begin{array}{l}\text { Double Crop } \\
\text { Agri Land }\end{array}$ & 3 \\
\hline & & $\begin{array}{l}\text { Triple Crop } \\
\text { Agri Land }\end{array}$ & 9 \\
\hline & & Commercial & 7 \\
\hline & & Waterbody & 5 \\
\hline & & Vacant & 5 \\
\hline & & Forest & 9 \\
\hline & & Recreation & 7 \\
\hline & & Residential & 7 \\
\hline & & Industrial & 6 \\
\hline & & $\begin{array}{l}\text { Community } \\
\text { Services }\end{array}$ & 7 \\
\hline & & $\begin{array}{ll}\text { Education } \quad \& \\
\text { Research }\end{array}$ & 7 \\
\hline & & Administrative & 9 \\
\hline & & Health Facility & 6 \\
\hline & & Economic Zone & 9 \\
\hline & & Service Activity & 5 \\
\hline & & Miscellaneous & 7 \\
\hline & & Mixed Use & 9 \\
\hline & & Road & 7 \\
\hline & & NO DATA & $\begin{array}{l}\text { NO } \\
\text { DATA }\end{array}$ \\
\hline
\end{tabular}

Table 17

Water logging has the highest influence

Table 16

\begin{tabular}{|c|c|c|c|}
\hline Variable & Influence & Field & Score \\
\hline \multirow[t]{5}{*}{ DEM } & \multirow[t]{5}{*}{12} & 1 & 1 \\
\hline & & 2 & 3 \\
\hline & & 3 & 5 \\
\hline & & 4 & 7 \\
\hline & & 5 & 9 \\
\hline \multirow[t]{5}{*}{ Infrastructure } & \multirow[t]{5}{*}{17} & 1 & 1 \\
\hline & & 2 & 3 \\
\hline & & 3 & 5 \\
\hline & & 4 & 7 \\
\hline & & 5 & 9 \\
\hline \multirow{5}{*}{$\begin{array}{l}\text { Ground water } \\
\text { recharge }\end{array}$} & \multirow[t]{5}{*}{12} & 1 & 1 \\
\hline & & 2 & 3 \\
\hline & & 3 & 5 \\
\hline & & 4 & 7 \\
\hline & & 5 & 9 \\
\hline \multirow{5}{*}{$\begin{array}{l}\text { Distance from } \\
\text { Road }\end{array}$} & \multirow[t]{5}{*}{12} & 1 & 1 \\
\hline & & 2 & 3 \\
\hline & & 3 & 5 \\
\hline & & 4 & 7 \\
\hline & & 5 & 9 \\
\hline \multirow{3}{*}{$\begin{array}{l}\text { Water } \\
\text { Logging }\end{array}$} & \multirow[t]{3}{*}{30} & 1 & 1 \\
\hline & & 2 & 3 \\
\hline & & 3 & 5 \\
\hline
\end{tabular}

\begin{tabular}{|c|c|c|c|}
\hline \multicolumn{4}{|c|}{ Infrastructure Conflict has the highest influence } \\
\hline Variable & Influence & Field & Score \\
\hline \multirow[t]{5}{*}{ DEM } & \multirow[t]{5}{*}{12} & 1 & 1 \\
\hline & & 2 & 3 \\
\hline & & 3 & 5 \\
\hline & & 4 & 7 \\
\hline & & 5 & 9 \\
\hline \multirow[t]{5}{*}{ Infrastructure } & \multirow[t]{5}{*}{30} & 1 & 1 \\
\hline & & 2 & 3 \\
\hline & & 3 & 5 \\
\hline & & 4 & 7 \\
\hline & & 5 & 9 \\
\hline \multirow{5}{*}{$\begin{array}{l}\text { Ground water } \\
\text { recharge }\end{array}$} & \multirow[t]{5}{*}{12} & 1 & 1 \\
\hline & & 2 & 3 \\
\hline & & 3 & 5 \\
\hline & & 4 & 7 \\
\hline & & 5 & 9 \\
\hline \multirow{4}{*}{$\begin{array}{l}\text { Distance from } \\
\text { Road }\end{array}$} & \multirow[t]{4}{*}{12} & 1 & 1 \\
\hline & & 2 & 3 \\
\hline & & 3 & 5 \\
\hline & & 4 & 7 \\
\hline
\end{tabular}


ISSN No:-2456-2165

\begin{tabular}{|c|c|c|c|}
\hline & & 4 & 7 \\
\hline & & 5 & 9 \\
\hline Land Use & 17 & $\begin{array}{l}\text { Single Crop } \\
\text { Agri Land }\end{array}$ & 1 \\
\hline & & $\begin{array}{l}\text { Double Crop } \\
\text { Agri Land }\end{array}$ & 3 \\
\hline & & $\begin{array}{l}\text { Triple Crop } \\
\text { Agri Land }\end{array}$ & 9 \\
\hline & & Commercial & 7 \\
\hline & & Waterbody & 5 \\
\hline & & Vacant & 5 \\
\hline & & Forest & 9 \\
\hline & & Recreation & 7 \\
\hline & & Residential & 7 \\
\hline & & Industrial & 6 \\
\hline & & $\begin{array}{l}\text { Community } \\
\text { Services }\end{array}$ & 7 \\
\hline & & $\begin{array}{l}\text { Education } \quad \& \\
\text { Research }\end{array}$ & 7 \\
\hline & & Administrative & 9 \\
\hline & & Health Facility & 6 \\
\hline & & Economic Zone & 9 \\
\hline & & Service Activity & 5 \\
\hline & & Miscellaneous & 7 \\
\hline & & Mixed Use & 9 \\
\hline & & Road & 7 \\
\hline & & NO DATA & NO DATA \\
\hline
\end{tabular}

Table 18

\begin{tabular}{|c|c|c|c|}
\hline \multicolumn{4}{|c|}{ Land use has the highest influence } \\
\hline Variable & Influence & Field & Score \\
\hline \multirow[t]{5}{*}{ DEM } & \multirow[t]{5}{*}{12} & 1 & 1 \\
\hline & & 2 & 3 \\
\hline & & 3 & 5 \\
\hline & & 4 & 7 \\
\hline & & 5 & 9 \\
\hline \multirow[t]{5}{*}{ Infrastructure } & \multirow[t]{5}{*}{17} & 1 & 1 \\
\hline & & 2 & 3 \\
\hline & & 3 & 5 \\
\hline & & 4 & 7 \\
\hline & & 5 & 9 \\
\hline \multirow{5}{*}{$\begin{array}{l}\text { Ground water } \\
\text { recharge }\end{array}$} & \multirow[t]{5}{*}{12} & 1 & 1 \\
\hline & & 2 & 3 \\
\hline & & 3 & 5 \\
\hline & & 4 & 7 \\
\hline & & 5 & 9 \\
\hline \multirow{5}{*}{$\begin{array}{l}\text { Distance from } \\
\text { Road }\end{array}$} & \multirow[t]{5}{*}{12} & 1 & 1 \\
\hline & & 2 & 3 \\
\hline & & 3 & 5 \\
\hline & & 4 & 7 \\
\hline & & 5 & 9 \\
\hline \multirow[t]{5}{*}{ Water Logging } & \multirow[t]{5}{*}{17} & 1 & 1 \\
\hline & & 2 & 3 \\
\hline & & 3 & 5 \\
\hline & & 4 & 7 \\
\hline & & 5 & 9 \\
\hline \multirow[t]{2}{*}{ Land Use } & \multirow[t]{2}{*}{30} & $\begin{array}{l}\text { Single Crop } \\
\text { Agri Land }\end{array}$ & 1 \\
\hline & & Double $\quad$ Crop & 3 \\
\hline
\end{tabular}

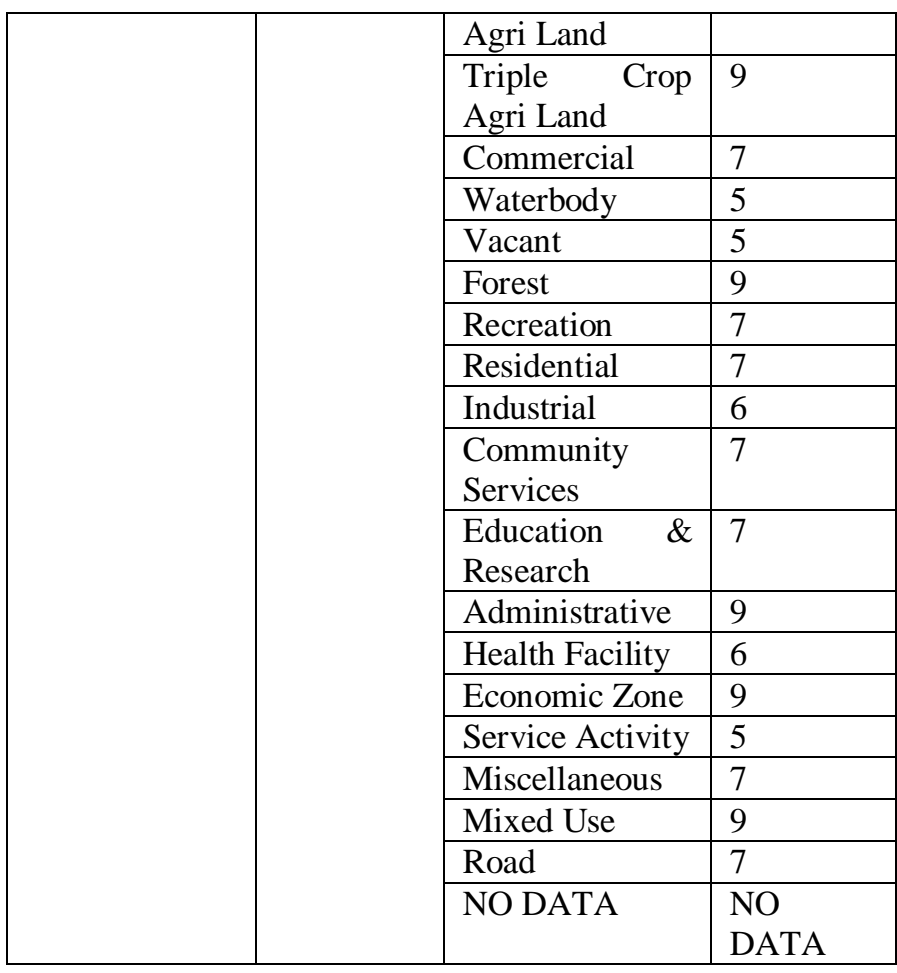

Table 19

\section{J. Development Conflict Map}

Finally, to achieve the most reliable result, an average of these four outputs from four different conditions were calculated and considered as the final Conflict map for Mirsharai Upazila development Plan (MUDP) project area.

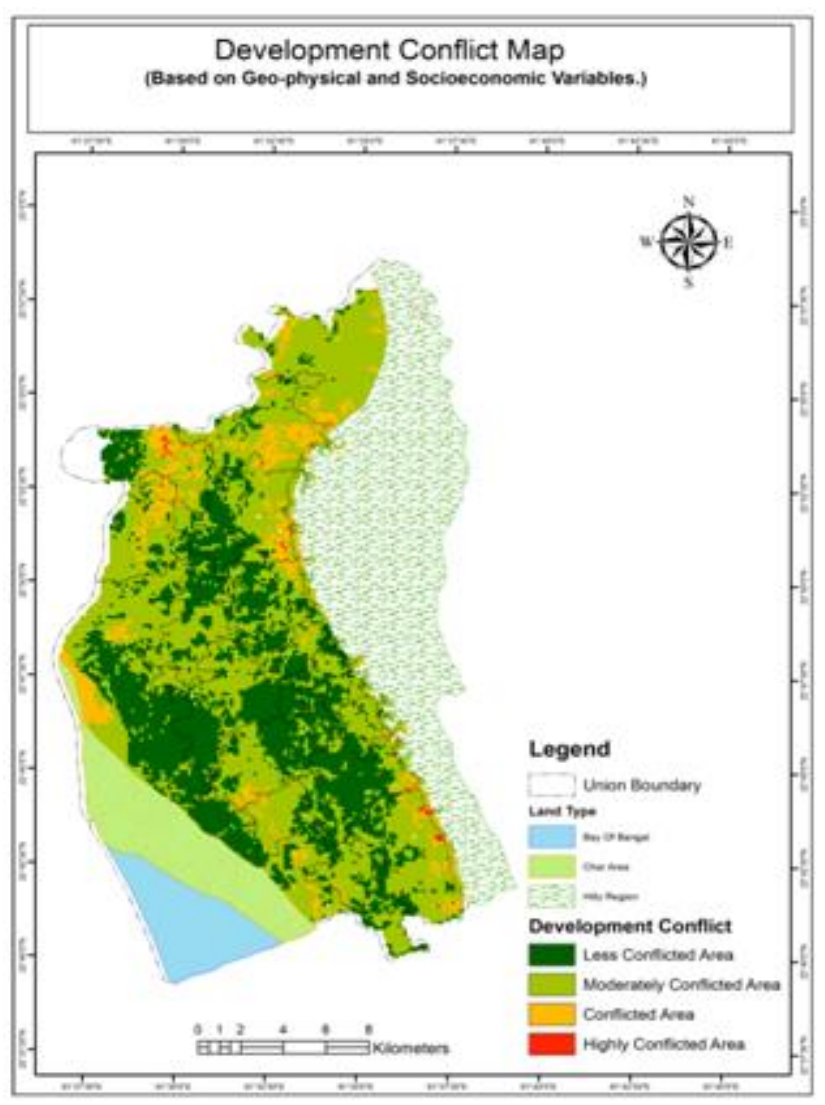

Fig. 9:- Development Conflict Map 


\section{SUITABILITY VS CONFLICT}

In final stage, Conflict values were subtracted from Suitability values. Here, vegetative values represent that those areas are not suitable for any type of development, zero values represent that, in those places, Conflict and suitability values are the same and positive values indicates the suitability for development.

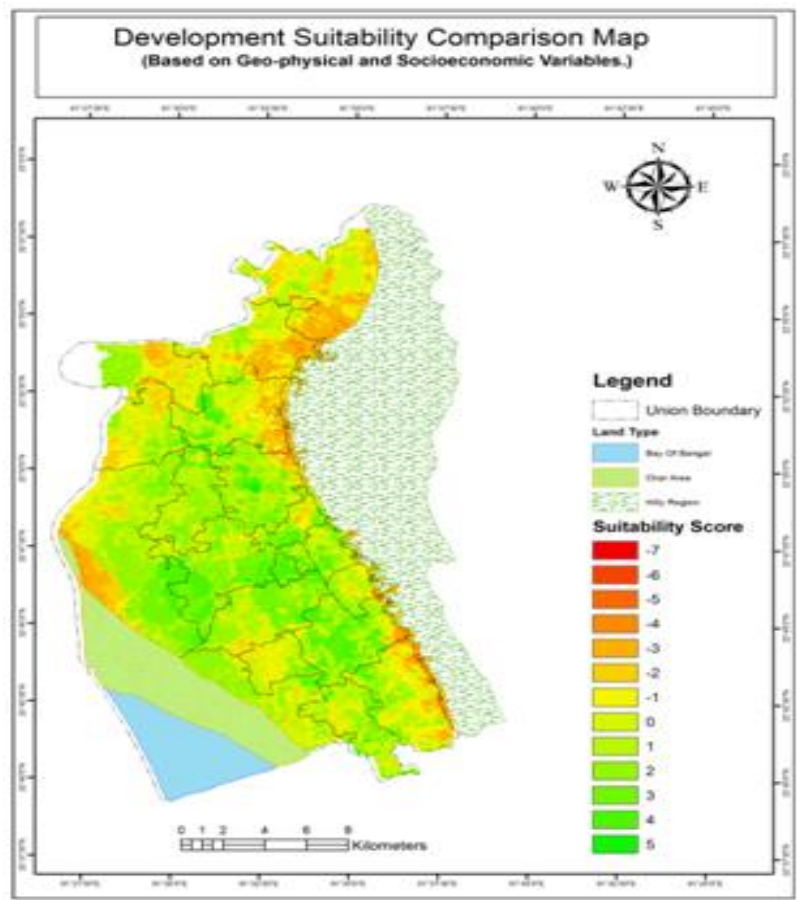

Fig. 10:- Development suitability comparison map with score

Finally, the value range has been classified as highly suitable area to completely unsuitable area.

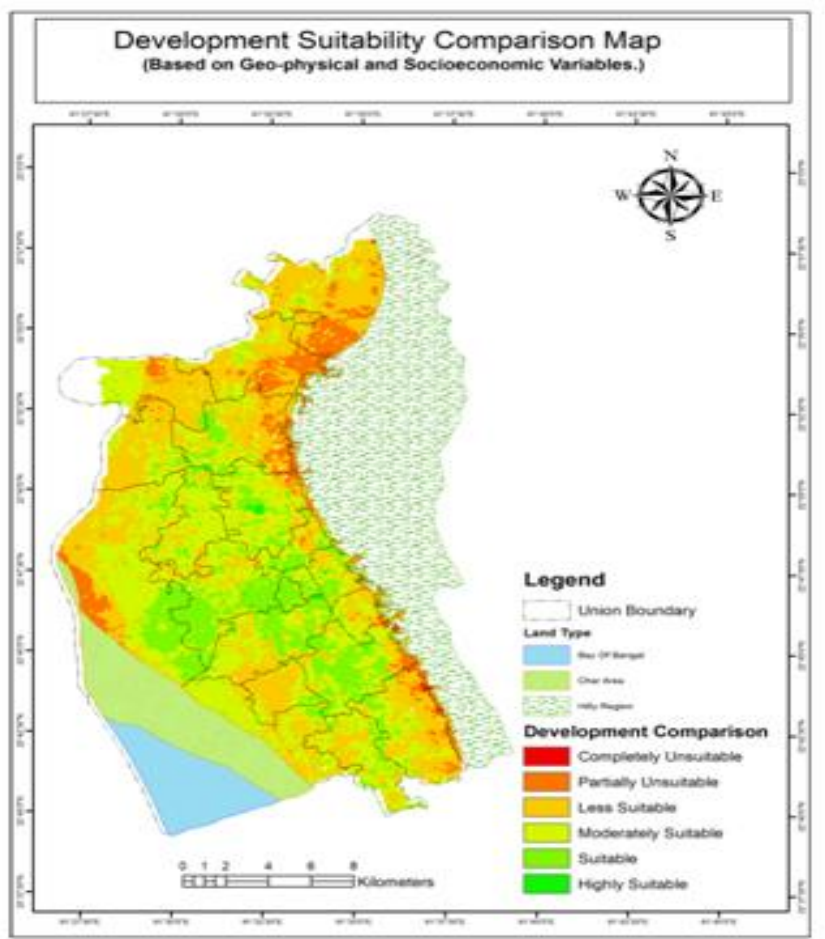

Fig. 11:- Development suitability Comparison Map

\section{RECOMMENDATIONS}

For new development or urban expansion, most development suitable areas should be selected because these areas are geo-physically in better state than other areas. At the same time, strong physical infrastructure and utility facility is needed in less suitable areas to improve suitability and reduce vulnerability.

Diversification is income generating sectors will be helpful to generate more income opportunities for people which will improve affordability and overall economic growth of the area.

\section{CONCLUSION}

Mirsharai is a least developed Upazila. Some economic growth can be seen within 2 urban areas and some of the growth centres. But overall economy is not in sustainable development stage. So, large scale income generating activities are required. The area is also geographically challenged because a large portion of land of the Upazila is hilly area. Considering the result from development suitability analysis, a significant amount of area is not suitable for development. So, urgent infrastructural development is necessary to reduce vulnerability and increase suitability for development.

\section{ACKNOWLEDGEMENT}

Special acknowledgement to Urban Development Directorate (UDD) under Ministry of Housing and Public works, Government of the People republic of Bangladesh for this amazing opportunity of studying alongside their plan preparation work Under the project "Preparation of Development Plan for Mirsharai Upazila, Chattogram District Risk Sensitive Land Use Plan (MUDP)"

Special acknowledgement to Director Khurshid Zabin Hossain Taufiq, Project Director Ahmed Akhtaruzzaman (MUDP Project) and Urban Planners associated with MUDP Project for their help and support.

Special acknowledgement to Geomark Limited (Consulting Firm, MUDP Project) and associated stuffs for the support.

\section{REFERENCES}

[1]. Collins, Michael \& Steiner, Frederick \& Rushman, Michael. (2001). Land-Use Suitability Analysis in the United States: Historical Development and Promising Technological Achievements. Environmental management. 28. 611-21. 10.1007/s002670010247.

[2]. Hopkins, L., 1977. Methods for generating land suitability maps: a comparative evaluation. J. Am. Inst. Planners 34 (1), 19-29.

[3]. Jiang, H., Eastman, J.R., 2000. Application of fuzzy measures in multi-criteria evaluation in GIS. Int. J. Geogr. Inform. Syst. 14, 173-184. 
[4]. Kumar, M., Shaikh, V.R. Site Suitability Analysis for Urban Development Using GIS Based Multicriteria Evaluation Technique. J Indian Soc Remote Sens 41, 417-424

(2013). https://doi.org/10.1007/s12524-012-0221-8

[5]. Malczewski, J., 1996. A GIS-based approach to multiple criteria group decision making. International Journal of Geographical Information Systems 10(8), 955-971.

[6]. Malczewski, J. (2006). Ordered weighted averaging with fuzzy quantifiers: GIS-based multicriteria evaluation for land-use suitability analysis. International Journal of Applied Earth Observation and Geoinformation. 8: 270-277.

[7]. Miller W, Collins W, Steiner FR, Cook E (1998) An approach for greenway suitability analysis landscape and urban planning. Int $\mathbf{J}$ Geogr Inform Sci 42(2-4):91-105

[8]. Prakash T (2003) Land suitability analysis for agricultural crops: a fuzzy multicriteria decision making approach. MS Theses, International institute for geo-information science and earth observation Enschede, The Netherlands

[9]. "Population Census Wing, BBS". Archived from web.archive.org. Retrieved September 9, 2020. url: https://web.archive.org/web/20050327072826/http://w ww.bangladeshgov.org/mop/ndb/arpc91_v1/tables04.h tm

[10]. Steiner F, McSherry L, Cohen J (2000) Land suitability analysis for the upper Gila River watershed. Landsc Urban Plan 50:199-214 